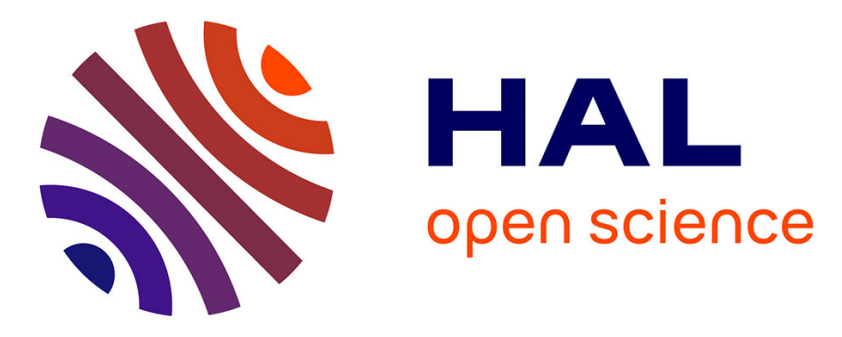

\title{
Diastereomeric stilbenoid glucoside dimers from the rhizomes of Gnetum africanum
}

\author{
Julien Gabaston, Thierry Buffeteau, Thierry Brotin, Jonathan Bisson, \\ Caroline Rouger, Jean-Michel Mérillon, Pierre Waffo-Téguo
}

\section{To cite this version:}

Julien Gabaston, Thierry Buffeteau, Thierry Brotin, Jonathan Bisson, Caroline Rouger, et al.. Diastereomeric stilbenoid glucoside dimers from the rhizomes of Gnetum africanum. Phytochemistry Letters, 2020, 39, pp.151-156. 10.1016/j.phytol.2020.08.004 • hal-03016445

\section{HAL Id: hal-03016445 \\ https://hal.science/hal-03016445}

Submitted on 20 Nov 2020

HAL is a multi-disciplinary open access archive for the deposit and dissemination of scientific research documents, whether they are published or not. The documents may come from teaching and research institutions in France or abroad, or from public or private research centers.
L'archive ouverte pluridisciplinaire HAL, est destinée au dépôt et à la diffusion de documents scientifiques de niveau recherche, publiés ou non, émanant des établissements d'enseignement et de recherche français ou étrangers, des laboratoires publics ou privés. 


\section{Diastereomeric Stilbenoid Glucoside Dimers from the Rhizomes of Gnetum}

2 africanum

3 Julien Gabaston ${ }^{\mathrm{a}}$, Thierry Buffeteau ${ }^{\mathrm{b}}$, Thierry Brotin ${ }^{\mathrm{c}}$, Jonathan Bisson ${ }^{\mathrm{a}}$, Caroline Rouger ${ }^{\mathrm{a}}$,

4 Jean-Michel Mérillon ${ }^{\mathrm{a}}$, and Pierre Waffo-Téguo ${ }^{\mathrm{a}, *}$

5

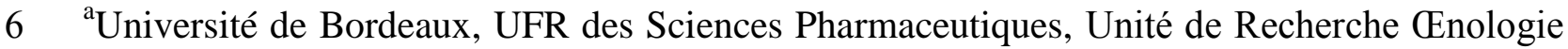

7 EA 4577, USC 1366 INRAE - Institut des Sciences de la Vigne et du Vin, CS 50008 - 210 ,

8 chemin de Leysotte, 33882 Villenave d'Ornon, France.

9 buniversité Bordeaux, Institut des Sciences Moléculaires, UMR 5255 - CNRS, 351 Cours de 10 la Libération, F-33405 Talence, France.

$11{ }^{c}$ Université Lyon 1, Ecole Normale Supérieure de Lyon, CNRS UMR 5182, Laboratoire de 12 Chimie, 69364 Lyon, France.

14 Corresponding Author:

15 *Tel.: +33-55-757-5955. Fax:+33-55-757-5952. E-mail: pierre.waffo-teguo@u-bordeaux.fr.

16 Université de Bordeaux, UFR des Sciences Pharmaceutiques, Unité de Recherche Enologie

17 EA 4577, USC 1366 INRAE - Institut des Sciences de la Vigne et du Vin, CS 50008 - 210,

18 chemin de Leysotte, 33882 Villenave d'Ornon, France.

19 


\section{ABSTRACT:}

21 In a continuing search for neuroprotective stilbenoids, two uncommon diastereomeric 22 stilbenoid glucosides, africanoside A (1) and B (2) as well as fifteen known stilbenes, $E$ resveratrol, $E$-gnetifolin E, $E$-piceid, $E$-resveratroloside, $E$-gnetifolin $\mathrm{K}, E$-gnetol, $E$ isorhapontigenin, $E$-isorhapontin, $E$-isorhapontigenin-4'- $O$-glucopyranoside, $E$-gnetin $\mathrm{C}, E$ bisisorhapontigenin $\mathrm{B}, E$-gnemonoside A, $E$-gnemonoside C, $E$-gnemonoside $\mathrm{D}$, and $E$-gnetin E, were isolated from rhizomes of Gnetum africanum, using a combination of centrifugal partition chromatography and preparative HPLC. The structure of these two stilbenoids was investigated by NMR, vibrational circular dichroism (VCD), and electronic circular dichroism (ECD) experiments. The absolute configurations of $\mathbf{1}$, and $\mathbf{2}$ were established by VCD as $(7 \mathrm{a} S, 8 \mathrm{a} S)$ and $(7 \mathrm{a} R, 8 \mathrm{a} R)$, respectively. Compound 1 significantly chelated Fe(II) at 100, 250 and $500 \mu \mathrm{M}$. The ability of stilbenoids to chelate ferrous ions which are implicated in physiopathological hallmark of Alzheimer's disease provides useful data for potential treatment.

Keywords: Gnetum africanum, Gnetaceae, stilbenoids, polyphenols, absolute configuration, iron chelation 


\section{Introduction}

The genus Gnetum is the only one of the Gnetaceae family. It consists of 40 species, mostly lianas, distributed in the tropical and subtropical regions of Asia, South America and Central Africa. In Africa, four different species of Gnetum, G. africanum, G. bucholzianum, G. interruptum, and G. latispicum have been described on the basis of morphologies features (Biye et al., 2014). The african gnetums are distributed in the humid tropical forests, which extend from Nigeria to Angola, via Cameroon, the Central African Republic, Gabon and the Democratic Republic of Congo (Biye et al., 2014). The African species are dioecious lianas. In Cameroon, gnetum also called "Eru", is one of the most important native vegetable with a high economic values. Market studies indicate that more than 3600 tons of gnetum leaves are annually exported from Cameroon (Kanmegne et al., 2007). G. africanum and $G$. bucholzianum are used as vegetables, eaten raw or cooked in soups and salads. The aerial parts are used traditionally to treat diabetes, arterial hypertension; as a medicine against sore throat; and as a purgative (“Gnetum africanum (PROTA),"). Many studies have shown that the leaves of African species such as G. africanum and G. bucholzianum give a significant nutritional and antioxidant activity (Ali et al., 2011; Mvitu-Muaka et al., 2012; Ogbonnaya and Chinedum, 2013). The compounds isolated from the plants of Gnetum genus included $C$ glycosylflavones, specially from the leaves of G. africanum and G. bucholzianum (Ouabonzi et al., 1983); flavonostilbenes (Iliya et al., 2003b); and stilbenoids, specially from lianas of $G$. hainanense (Huang et al., 2000), G. montanum (Li et al., 2004), G. parvifolium (Tanaka et al., 2001), stem of G. gnemonoides (Iliya et al., 2001), bark of G. cuspidatum (Shimokawa et al., 2012), seeds and roots of G. gnemon (Iliya et al., 2003a; Kato et al., 2009), and roots of G. macrostachyum (Sri-in et al., 2011). In our recent work, two diastereoisomers of gnemonoside A were isolated from the rhizomes of G. africanum and the absolute configuration was established by vibrational circular dichroism (VCD) spectroscopy (Buffeteau et al., 2014). As a part of our continuing research for plant-derived neuroprotective agents, a fractionation of a 
G. africanum rhizome extract resulted in the isolation of two novel dimeric stilbenes glucosides, africanoside A (1) and B (2), which were purified along with fifteen known stilbenes, using solvent extraction and a combination of HPLC and centrifugal partition chromatography. The present work deals with the structure elucidation and iron chelating activity of compounds $\mathbf{1}$ and $\mathbf{2}$ (Figure 1).

\section{Results and Discussion}

Dried and powdered rhizomes of $G$. africanum were defatted with toluene. The defatted powder was extracted with aqueous acetone. The hydroacetonic extract was concentrated at $35{ }^{\circ} \mathrm{C}$ under reduced pressure. To enhance the stilbenoid content, aqueous residue was prepurified on Amberlite XAD-7 $\left(\mathrm{H}_{2} \mathrm{O}\right.$ and acetone) to provide a semipurified enriched extract (GA). GA was further partitioned between EtOAc and $\mathrm{H}_{2} \mathrm{O}$. The organic and aqueous extracts were concentrated and freeze-dried. The organic extract (GAE) was purified by a combination of centrifugal partition chromatography and preparative HPLC over $\mathrm{C}_{18}$ reversed phase. From these extract, the known compounds were identified as $E$-resveratrol, $E$-gnetol, $E$-piceid, $E$-isorhapontigenin, $E$-isorhapontin, $E$-gnetifolin E, $E$-gnemonoside $\mathrm{C}, \quad E$ gnemonoside $\mathrm{D}, E$-gnetin $\mathrm{C}, E$-bisisorhapontigenin $\mathrm{B}$, and $E$-gnetin $\mathrm{E}$, by comparison of physicochemical data with those reported in the literature (Boralle et al., 1993; Buffeteau et al., 2014; Fernández-Marín et al., 2012; Iliya et al., 2002; Lins et al., 1982; Xu and Lin, 1997). The aqueous extract (GAA) was purified by preparative HPLC over $\mathrm{C}_{18}$ reversed phase to afford two new compounds $\mathbf{1}$ and $\mathbf{2}$ along with six known stilbenes, $E$-resveratrol-3,4'-Odiglucopyranoside, $E$-gnetifolin $\mathrm{K}, E$-resveratroloside, $E$-isorhapontin, $E$-gnemonoside A. The spectroscopic data of these known stilbenes were found to be similar with those reported in the literature (Buffeteau et al., 2014; Larronde et al., 2005; Waffo Teguo et al., 1998).

Compound 1 gave a $[\mathrm{M}-\mathrm{H}]^{-}$HRESIMS quasi-molecular ion peak at $\mathrm{m} / \mathrm{z}$ 807.2512, consistent with the molecular formula $\mathrm{C}_{41} \mathrm{H}_{44} \mathrm{O}_{17}$. The presence of ions at $\mathrm{m} / z 645.1983$ and 
$m / z$ 483.1436, corresponding to a neutral loss of two $\mathrm{C}_{6} \mathrm{H}_{10} \mathrm{O}_{5}$, suggested that compound $\mathbf{1}$ contains two hexosyl groups. Moreover, the empirical formula of the ion at 483.1436 corresponded to a dimer of resveratrol with an additional methoxy group.

Assignments of all ${ }^{1} \mathrm{H}$ and ${ }^{13} \mathrm{C}$ NMR signals for compound $\mathbf{1}$ were achieved by the analysis of ${ }^{1} \mathrm{H}-{ }^{1} \mathrm{H}$ COSY, ${ }^{1} \mathrm{H}_{-}{ }^{13} \mathrm{C}$ HSQC, ${ }^{1} \mathrm{H}_{-}{ }^{13} \mathrm{C}$ HMBC data (Table 1). The ${ }^{1} \mathrm{H}$ NMR spectrum showed the presence of two regions of signals with a characteristic resonance. The former, between $\delta_{\mathrm{H}} 7.2$ and 6, consisted of an ABC-spin system $\left[\delta_{\mathrm{H}} 7.20(\mathrm{H}-2 \mathrm{~b}), \delta_{\mathrm{H}} 7.16(\mathrm{H}-5 b)\right.$, and $\delta_{\mathrm{H}} 7.08$ (H-6b)], an $\mathrm{AA}^{\prime} \mathrm{BB}^{\prime}-$ spin system $\left[\delta_{\mathrm{H}} 7.26(\mathrm{H}-2 \mathrm{a}\right.$ and $\mathrm{H}-6 \mathrm{a}), \delta_{\mathrm{H}} 7.10(\mathrm{H}-3 \mathrm{a}$ and $\left.\mathrm{H}-5 \mathrm{a})\right]$, an $\mathrm{AB}_{2}$-spin system $\left[\delta_{\mathrm{H}} 6.13(\mathrm{H}-10 \mathrm{a}\right.$ and $\left.\mathrm{H}-14 \mathrm{a}), \delta_{\mathrm{H}} 6.16(\mathrm{H}-12 \mathrm{a})\right]$, a 1,3,4,5-tetra substituted phenyl ring $\left[\delta_{\mathrm{H}} 6.54(\mathrm{H}-10 \mathrm{~b}), \delta_{\mathrm{H}} 6.68(\mathrm{H}-14 \mathrm{~b})\right]$, and two coupled doublets at $\delta_{\mathrm{H}} 7.05(\mathrm{H}-7 \mathrm{~b})$ and $\delta_{\mathrm{H}} 6.99(\mathrm{H}-8 \mathrm{~b})$ with a large coupling constant $(J=16.3 \mathrm{~Hz})$ for a $E$-olefinic proton system. The second region between $\delta_{\mathrm{H}} 6$ and 3, was characterized by two doublets at $\delta_{\mathrm{H}} 5.40$ (H-7a) and $\delta_{\mathrm{H}} 4.33$ (H-8a) for a dihydrobenzofuran moiety, a singlet at $\delta_{\mathrm{H}} 3.92$ (3b-OMe), and two overlapped doublets at $\delta_{\mathrm{H}} 4.92\left(\mathrm{H}-1^{\prime}\right.$ and $\left.\mathrm{H}-1^{\prime \prime}\right)$ for the proton at the anomeric center of the two hexose units. The complete assignments of each glycosidic proton spin system were achieved by analysis of COSY and TOCSY experiments. Also, the ${ }^{13} \mathrm{C}$ NMR spectrum showed a completed overlapping of six signals at $\delta_{C} 101.2,73.6,76.8,70.1,76.8$, and 61.3 ppm which are characteristic for a glucose unit (Waffo Teguo et al., 1998). The proton at anomeric center at $\delta_{\mathrm{H}} 4.92(1 \mathrm{H}, d, J=7.6 \mathrm{~Hz})$ indicated the existence of $\beta$-glucosyl residues. Therefore, compound $\mathbf{1}$ could be proposed as a diglucopyranoside of gnetin C-O-methylated. The position of glucosyl residues in compound $\mathbf{1}$ was determined by HMBC experiment, which showed long-range correlations between the $\mathrm{H}-1^{\prime}$ and $\mathrm{H}-1^{\prime \prime}$ of glucose at $\delta_{\mathrm{H}} 4.92$ and C-4a and C-4b at $\delta_{\mathrm{C}} 157.6$ and 146.4 , respectively. The position of the methoxyl group was also confirmed by a long-range correlation between the proton of methoxyl at $\delta_{\mathrm{H}} 3.92$ and C$3 \mathrm{~b}$ at $\delta_{\mathrm{C}} 150$. The absence of a cross-peak between the protons $\mathrm{H}-7 \mathrm{a}\left(\delta_{\mathrm{H}} 5.4\right)$ and $\mathrm{H}-8 \mathrm{a}$ 
$115\left(\delta_{\mathrm{H}} 4.33\right)$ in the ROESY spectrum (Supporting Information, Figure S3), indicated a trans-

116 orientation of these two protons. The structure of the new compound $\mathbf{1}$ was assigned as

117 gnemonoside A-3b-methoxyl and named africanoside A.

118 Compound 2 gave a $[\mathrm{M}-\mathrm{H}]^{-}$HRESIMS quasi-molecular ion peak at $\mathrm{m} / \mathrm{z}$ 807.2514 indicating

119 a molecular mass of $808 \mathrm{amu}$ in agreement with the molecular formula $\mathrm{C}_{41} \mathrm{H}_{44} \mathrm{O}_{17}$. The 120 presence of ions at $\mathrm{m} / \mathrm{z}, 645.1984$ and $\mathrm{m} / \mathrm{z}, 483.1440$, corresponding to a neutral loss of two

$121 \mathrm{C}_{6} \mathrm{H}_{10} \mathrm{O}_{5}$, suggesting that compound 2 contains two hexosyl group. Moreover, the empirical

122 formula of the ion at 483.1440 corresponded to a dimer of resveratrol with an additional 123 methoxy group. The ${ }^{1} \mathrm{H}$ and ${ }^{13} \mathrm{C}$ NMR spectra (Table $\mathbf{1}$ ) of compounds $\mathbf{1}$ and $\mathbf{2}$ were 124 superimposable, suggesting that the structures of both compounds were very similar. Thus, 125 the structure of $\mathbf{2}$ was concluded to be a gnemonoside A-3b-methoxyl isomer and named 126 africanoside B.

127 The relative configurations of the chiral centers (C-7a and C-8a) of compounds $\mathbf{1}$ and $\mathbf{2}$ were 128 deduced in the same manner as for the two diastereomers of (-)-E-gnemonoside A (Buffeteau 129 et al., 2014), using vibrational circular dichroism (VCD). VCD spectra of $\mathbf{1}$ and $\mathbf{2}$ were 130 recorded in DMSO- $d_{6}$ at a concentration of $50 \mathrm{mM}$ and are reported in Figure $2 \mathbf{a}$. The two 131 spectra are not perfectly opposite with respect to the baseline, revealing that the two 132 molecules are not enantiomers, but diastereomers. Indeed, since the glucopyranosyl (Glc) 133 groups have the same chirality ( $\beta$-D-Glc) for the two molecules, $\mathbf{1}$ and $\mathbf{2}$ are diastereoisomers.

134 Nevertheless, the VCD spectra of compounds $\mathbf{1}$ and $\mathbf{2}$ are quasi identical to those published 135 for the two diastereomers of (-)-E-gnemonoside A (Buffeteau et al., 2014). The VCD spectra 136 of the aglycone of the two diastereomers of (-)-E-gnemonoside A (ca (+)-E-gnetin $\mathrm{C}$ and (-)$137 E$-gnetin C) associated with DFT calculations allowed us to determine the absolute 138 configuration of these two enantiomers as (-)-(7aS,8aS)-E-gnetin $\mathrm{C}$ and (+)-(7aR,8aR)-E139 gnetin C. In this study, the VCD spectrum of compound $\mathbf{1}$ is well reproduced by the one 140 published for $(7 \mathrm{a} S, 8 \mathrm{a} S)$ - $E$-gnemonoside $\mathrm{A}$, and in turn, VCD spectrum of compound 2 is well 
141 reproduced by the one published for $(7 \mathrm{a} R, 8 \mathrm{a} R)-E$-gnemonoside $\mathrm{A}$.

142 As electronic circular dichroism (ECD) experiments are currently used in the structural

143 studies of stilbenes, ECD spectra of $\mathbf{1}$ and $\mathbf{2}$ are reported in Figure $\mathbf{2 b}$. The ECD spectrum of

1441 exhibits two positive bands at 222 and $252 \mathrm{~nm}$ and a broad negative band between 262 and

$145350 \mathrm{~nm}$. A similar ECD spectrum has been measured for (-)-E-gnetin C compound

146 (Supporting Information, Figure S19) for which the $(7 a S, 8 a S)$ configuration has been

147 determined (Buffeteau et al., 2014).

148 Compounds $\mathbf{1}$ and 2, as well as eight known stilbenes isolated from G. africanum organic and

149 aqueous extracts ( $E$-isorhapontigenin, $E$-gnetol, $E$-resveratroloside, $E$-isorhapontigenin-4'-O-

150 glucoside, $E$-gnetin $\mathrm{C}, E$-gnemonoside $\mathrm{A}, E$-gnemonoside $\mathrm{C}, E$-gnemonoside $\mathrm{D})$ were

151 evaluated for their iron-chelating activity. As presented in Figure $\mathbf{3}$, the compound $\mathbf{1}$

152 significantly chelated $\mathrm{Fe}(\mathrm{II})$ at $38.5 \%, 61.3 \%$ and $73.1 \%$ at 100,250 and $500 \mu \mathrm{M}$,

153 respectively. E-Isorhapontigenin-4'-O-glucoside also exhibited notable chelation at $40.6 \%$ and

$15467.0 \%$ at 250 and $500 \mu \mathrm{M}$, respectively. The other tested compounds from G. africanum were

155 less active as chelators of $\mathrm{Fe}(\mathrm{II})$ giving rise values inferior to $40 \%$ at $500 \mu \mathrm{M}$ which was

156 similar to the data reported for $E$-resveratrol whose concentration for $50 \%$ of chelation of

$157 \mathrm{Fe}(\mathrm{II})$ was $746 \mu \mathrm{M}$ (Kantham et al., 2017). These findings may afford beneficial effects into

158 Alzheimer's disease (AD) treatment. The physiopathological hallmark of AD is an abnormal

159 fibrillation and accumulation of amyloid beta peptide $(\mathrm{A} \beta)$ forming amyloid plaques in brain.

160 This process leads to neurotoxic effects such as cell membrane perturbation and oxidative

161 stress among others (Hornedo-Ortega et al., 2018). Otherwise, the presence of metal binding

162 sites and the large amount of iron in the amyloid plaque can accelerate the fibril formation

163 modulating the morphology of $A \beta$ oligomers and improving the toxicity of $A \beta$ cores

164 (Kantham et al., 2017). In addition, the strong presence of ferrous ions could be a source of

165 reactive oxygen species (ROS) as $\mathrm{Fe}(\mathrm{II})$ is the catalyst of Fenton reaction arousing oxidative

166 stress and neurotoxic effects (Ayton et al., 2017). As a consequence, the ability of compounds 
1671 to chelate ferrous ions provides useful data for potential AD treatment. Furthermore, our

168 findings revealed different biological activities between the two new diastereoisomer forms $\mathbf{1}$

169 and 2. Even if the chemical structure is very similar, other authors have confirmed that most

170 of isomers show notable differences in several biological domains related to pharmacology,

171 bioavailability, toxicology, and metabolism process (Mc.Conathy and Owens, 2003; Nguyen

172 et al., 2006). In fact, stereoisomers of miyabenol C, a trimeric stilbene, have already exhibited

173 different inhibition on fibrillation of $\mathrm{A} \beta$ (Papastamoulis et al., 2015). As a consequence, the

174 chiral separation followed by the determination of absolute configuration of stereoisomers

175 should be promoted in order to discriminate their biological activities and to provide accurate

176 treatment.

\section{3. Conclusions}

178 The structural investigation of compounds depends widely on the choice of analytical tools. In

179 the present work, different techniques were applied to assure the orthogonality of the data.

180 The absolute configuration of two novel diastereomeric stilbenoid glucosides was successful

181 elucidated by using NMR, mass spectrometry, VCD, and ECD. (7aS,8aS)-Africanoside A (1)

182 and $(7 \mathrm{a} R, 8 \mathrm{a} R)$-africanoside $\mathrm{B}(2)$ were determined as dimers of resveratrol with an additional

183 methoxy group and two hexosyl group. These two compounds as well as others stilbenoids

184 from G. africanum exhibited a wide range of iron-chelating activities. These findings allowed

185 to gain into the knowledge for plant-derived neuroprotective agents. In addition, the different

186 activity between the two diastereoisomers africanoside A and B promote the chiral separation

187 to ensure a specific treatment.

\section{4. Experimental}

\section{4.1. General experimental procedures.}

$190{ }^{1} \mathrm{H}$ and ${ }^{13} \mathrm{C}$ NMR spectra were recorded on a Bruker Avance III $600 \mathrm{MHz}$ NMR spectrometer 191 and analyzed with Bruker Topspin software. Compounds were measured in $3 \mathrm{~mm}$ NMR 192 tubes, using $\mathrm{CD}_{3} \mathrm{OD}$ and acetone-d6 as the solvents. The specific optical rotations were 
193

194

195

196

197

198

199

200

201

202

203

204

205

206

207

determined in methanol at $20{ }^{\circ} \mathrm{C}$ on a JASCO P-2000 polarimeter using the sodium emission wavelength $(\lambda=589 \mathrm{~nm})$. The centrifugal partition chromatography (CPC) used in this study $\left(\right.$ FCPC $1000^{\circledR}$ ) was provided by Kromaton Technologies (Sainte-Gemmes-sur-Loire, France). The solvents were pumped by an ECOM IOTA S100 2-way binary high-pressure Isocratic pump. The samples were introduced into the CPC column via a high pressure injection valve equipped with a $50 \mathrm{~mL}$ sample loop. The CPC fractions were monitored with an ECOM FLASH 06 DAD detector, at wavelengths of 306 and $280 \mathrm{~nm}$. HPLC preparative separations were carried out using a Varian Prostar 345 UV-visible detector and a binary pump with a Phenomenex Kinetex XB-C18 AXIA packed $(5 \mu \mathrm{m}, 100 \AA$ A, $250 \times 21.4 \mathrm{~mm})$ column. The mobile phase was composed of two solvents: (A) $0.025 \%$ TFA in $\mathrm{H}_{2} \mathrm{O}$ and (B) $\mathrm{MeCN}$. HRESIMS data were acquired using a Q-Exactive Plus mass spectrometer (Thermo Scientific, Bremen, Germany) fitted with a heated electrospray ionization (H-ESI II) probe.

\subsection{Plant material.}

The rhizomes of Gnetum africanum were collected in Yaoundé (Centre Province, Cameron) in November 2013. A voucher specimen (accession number R-GA/2013) has been deposited in the Department of the Molécules d'Intérêt Biologique (MIB) at ISVV. The identification was confirmed by Mr. Victor Nana, Botanist of the Cameroon National Herbarium.

\subsection{Extraction and isolation.}

Dried and finely powdered rhizomes of G. africanum $(600 \mathrm{~g})$ were defatted twice $1.5 \mathrm{~L}$ of toluene. The extraction was carried out as follows: The defatted powder is moistened with $60 \%$ aqueous acetone and placed in the percolator. The percolator was filled with $60 \%$ aqueous acetone and covered up. The bottom outlet was opened until get a regular dripping and then closed and left macerated for $24 \mathrm{~h}$. After this time, the outlet bottom was opened and left dripping slowly. The maceration-percolation extraction was repeated 2 times and the hydroacetonic extract was concentrated at $35{ }^{\circ} \mathrm{C}$ under reduced pressure. To enhance the stilbenoid content, aqueous residue was prepurified on amberlite XAD-7 $\left(\mathrm{H}_{2} \mathrm{O}\right.$ and acetone), 
using the previously published protocol to provide a semi-purified extract enriched (GA, 51.43 g) (Buffeteau et al., 2014). $50 \mathrm{~g}$ of GA was further partitioned between EtOAc and $\mathrm{H}_{2} \mathrm{O}$. The organic and aqueous extracts were concentrated and freeze-dried to yield $28.87 \mathrm{~g}$ (EtOAc, GAE) and $17.6 \mathrm{~g}\left(\mathrm{H}_{2} \mathrm{O}\right.$, GAA), respectively.

1 and 2 were purified from $1 \mathrm{~g}$ of GAA by preparative HPLC using a Varian Prostar 345 UVvisible detector and a binary pump with a Phenomenex Kinetex 100-5 XB-C $\mathrm{C}_{18}(5 \mu \mathrm{m}, 250 \times$ $21.4 \mathrm{~mm}$ ) column with a security Guard. The mobile phase was composed of two solvents: (A) $0.025 \%$ TFA in $\mathrm{H}_{2} \mathrm{O}$ and (B) $\mathrm{MeCN}$ and the elution program at $21 \mathrm{~mL} / \mathrm{min}$ was $10 \% \mathrm{~B}(0$ $2 \mathrm{~min}), 10-30 \%$ B (2-22 min), 30-38\% B (22-37 min), 38-100\% B (37-45 min), 100\% B (45$50 \mathrm{~min}), 100-10 \% \mathrm{~B}(50-51 \mathrm{~min}), 10 \% \mathrm{~B}$ (51-60 min).

Preparative centrifugal partition chromatography separation of EtOAc extract (GAE) was 230 performed in quaternary Arizona-L system consisting of n-heptane/ethyl 231 acetate/methanol/water (2:3:2:3). Four Arizona solvent systems (J, K, L, and M) were tested in order to select the optimal system L. Three batches of $5 \mathrm{~g}$ were submitted to CPC separation in descending mode. In our experiment, the rotor was filled by injecting the organic lighter stationary phase at $50 \mathrm{~mL} / \mathrm{min}$ and $500 \mathrm{rpm}$. Then, the rotation speed was increased to 1000 rpm. The mobile phase was pumped into the column at $15 \mathrm{~mL} / \mathrm{min}$ until the equilibrium was reached and the sample solution containing $5 \mathrm{~g}$ of dry GAE dissolved in $40 \mathrm{~mL}$ of a mixture consisting of upper and lower phase $(1: 1, \mathrm{v} / \mathrm{v})$ was injected through a $50 \mathrm{~mL}$ loop. The CPC fractions were constituted according to the elution profile. The collected fraction were 239 evaporated and freeze-dried. A total of six fractions numbered from Fr 1 to Fr 6 were 240 obtained. Fr $1(1 \mathrm{~g})$ was subjected to preparative HPLC [(solvent A: $0.025 \%$ TFA in $\mathrm{H}_{2} \mathrm{O}$ and $241 \mathrm{~B}: \mathrm{MeCN}$; the elution program at $21 \mathrm{~mL} / \mathrm{min}$ was $10 \% \mathrm{~B}(0-2 \mathrm{~min}), 10-20 \% \mathrm{~B}(2-22 \mathrm{~min})$, $24220 \% \mathrm{~B}(22-35 \mathrm{~min}), 20-40 \% \mathrm{~B}(35-36 \mathrm{~min}), 40 \% \mathrm{~B}(36-40 \mathrm{~min}), 40 \% \mathrm{~B}$ (36-40 $\mathrm{min})]$ to 243 yield: $E$-resveratroloside (41.6 mg), E-isorhapontigenin-4'-O-glucoside (18.7 mg), $E$ 244 gnemonoside A (16.8 mg), E-piceid (28.5 mg), E-isorhapontin (12.3 mg), E-gnetol (10 mg), 
$E$-gnemonoside C (107.6 mg), and E-gnemonoside D $(34.7 \mathrm{mg})$. The purification of the Fr 5

246 (750 mg) was performed by preparative HPLC [the same mobile phases as above were used 247 and the elution program at $21 \mathrm{~mL} / \mathrm{min}$ was $17 \% \mathrm{~B}(0-2 \mathrm{~min}), 17-30 \% \mathrm{~B}(2-22 \mathrm{~min}), 30-38 \% \mathrm{~B}$ 248 (22-37 min), 38-100\% B (37-45 $\mathrm{min}), 100 \%$ B (45-50 min), 100-17\% B (50-51 min), 17\% B 249 (51-60 $\mathrm{min})$ ] to provide: $E$-resveratrol $(157 \mathrm{mg}), E$-isorhapontigenin $(59 \mathrm{mg}), E$-gnetin C (182 $250 \mathrm{mg}), E$-Bisisorhapontigenin B (46 mg), and E-gnetin E (5 mg).

251 Compound 1: white amorphous powder; $[\alpha]_{\mathrm{D}}{ }^{20}=-58.2(\mathrm{c}=0.086, \mathrm{MeOH}) ;{ }^{1} \mathrm{H}$ and ${ }^{13} \mathrm{C} \mathrm{NMR}$ 252 spectroscopic data, (see Table 1); HRESIMS [M-H] $]^{-} \mathrm{m} / \mathrm{z}$ 807.2519.

253 Compound 2: white amorphous powder; $[\alpha]_{\mathrm{D}}{ }^{20}=+22.6(\mathrm{c}=0.102, \mathrm{MeOH}) ;{ }^{1} \mathrm{H}$ and ${ }^{13} \mathrm{C} \mathrm{NMR}$ 254 spectroscopic data, (see Table 1); HRESIMS [M-H] $]^{-} \mathrm{m} / z$ 807.2517.

\subsection{UV-vis and ECD Measurements.}

ECD spectra of compounds $\mathbf{1}$ and $\mathbf{2}$ were recorded in $\mathrm{EtOH}$ at $20^{\circ} \mathrm{C}$ with a $1 \mathrm{~cm}$ path length quartz cell. The concentration of the two compounds was taken in the range $0.710^{-4}-1.10^{-4}$ M. Spectra were recorded in the $210-400 \mathrm{~nm}$ wavelength range with a $0.5 \mathrm{~nm}$ increment and a 1s integration time. Spectra were processed with standard spectrometer software, baseline corrected and slightly smoothed by using a third order least square polynomial fit. Spectral units were expressed in difference of molar extinction coefficients $(\Delta \varepsilon$ in $\mathrm{L} / \mathrm{mol} / \mathrm{cm})$.

\subsection{VCD measurements.}

IR and VCD spectra were recorded with a ThermoNicolet Nexus 670 FTIR spectrometer

264 equipped with a VCD optical bench (Buffeteau et al., 2005). In this optical bench, the light 265 beam was focused by a $\mathrm{BaF}_{2}$ lens (191 mm focal length) to the sample, passing an optical 266 filter, a $\mathrm{BaF}_{2}$ wire grid polarizer (Specac), and a $\mathrm{ZnSe}$ photoelastic modulator (Hinds 267 Instruments, Type II/ZS50). The light was then focused by a ZnSe lens (38.1 mm focal length) 268 onto a $1 \times 1 \mathrm{~mm}^{2} \mathrm{HgCdTe}$ (ThermoNicolet, MCTA* E6032) detector. IR and VCD spectra were 269 recorded at a resolution of $4 \mathrm{~cm}^{-1}$ by co-adding 50 scans and 36000 scans $(12 \mathrm{~h}$ acquisition 
time), respectively. The sample was held in a fixed path length $(100 \mu \mathrm{m})$ cell with $\mathrm{BaF}_{2}$ windows. IR and VCD spectra of compounds $\mathbf{1}$ and $\mathbf{2}$ were measured in DMSO- $d_{6}$ at a concentration of $50 \mathrm{mM}$. Baseline correction of the VCD spectra was performed by subtracting the VCD spectrum of DMSO- $d_{6}$ solvent. In all experiments, the photoelastic modulator was adjusted for a maximum efficiency at $1400 \mathrm{~cm}^{-1}$. Calculations were done with the standard ThermoNicolet software, using Happ and Genzel apodization, de-Haseth phasecorrection and a zero-filling factor of one. Calibration spectra were recorded using a birefringent plate $(\mathrm{CdSe})$ and a second $\mathrm{BaF}_{2}$ wire grid polarizer. Finally, the solvent absorption was subtracted out in the presented IR spectra.

\subsection{Iron chelating activity.}

The ferrozine assay protocol was used to estimate the concentration of free ferrous ions by measuring the absorbance of the Fe(II)-ferrozine complex at $560 \mathrm{~nm}$ (Chan et al., 2016). The decrease of absorbance allowed to evaluate the binding of Fe(II) to the tested compounds. The assay was performed according to previously published protocols with slight modifications (Chan et al., 2016; Dinis et al., 1994). Tests were carried out in 96 well plates and solutions were prepared in HEPES buffer (15 mM, pH 6.8). Briefly, $50 \mu \mathrm{L}$ of a Fe(II) solution at 200 $\mu \mathrm{M}$ was incubated with $50 \mu \mathrm{L}$ of pure compounds (E-gnetol, $E$-isorhapontigenin, $E$ isorhapontigenin-4'-O-glucoside, E-resveratroloside, E-gnetin C, E-gnemonoside A, Egnemonoside C, E-gnemonoside D, africanoside A and africanoside B) to reach the following final concentrations: $0,25,50,100,250,500 \mu \mathrm{M}$. To maximize the solubility of pure compounds, $\mathrm{MeOH}$ was used as co-solvent at final concentration of $1 \%(\mathrm{v} / \mathrm{v})$. Gallic acid was used as positive control. After $30 \mathrm{~min}$ of incubation, ferrozine at $1 \mathrm{mM}(50 \mu \mathrm{L})$ was added leading to the formation of purple complex. The reaction reached the equilibrium after $10 \mathrm{~min}$ of incubation. At this moment, absorbance at $560 \mathrm{~nm}$ was measured by an automated plate reader (Fluostar Omega; BMG Labtech, Offenburg, Germany). The chelation of Fe(II) values (\%) by compounds was calculated as follows (Kantham et al., 2017): 
Chelation $(\%)=\left(1-\left(A_{F e(I I)}+\right.\right.$ compound + ferrozine $-A_{F e}+$ compound $\left.) /\left(A_{F e(I I)+\text { ferrozine }}-A_{F e(I I)}\right)\right) x 100$

297 All assays were repeated at least in triplicate and performed in quadruplicate.

298 4.7. Statistical analysis.

299 Statistical analysis was carried out with one-way ANOVA followed by Newman-Keuls 300 multiple comparison post hoc tests. GraphPad Prism software v5.03 (La Jolla, CA) was used. 301 Significant differences between $\mathrm{Fe}(\mathrm{II})$ chelation percentage of pure compounds are 302 represented by different letters.

\section{Declaration of Competing Interest}

305 The authors declare no competing information.

\section{Funding}

308 This research was financially supported by the French Ministry of Research, the Aquitaine 309 Regional Government. NMR experiments were performed at MetaboHUB-Bordeaux facility 310 and supported by MetaboHUB (ANR-11-INBS-0010).

\section{Appendix A. Supplementary data}

313 Supporting Information: ${ }^{1}$ H NMR spectra of known stilbenoids in methanol-d4 or acetone-

314 d6. ${ }^{1} \mathrm{H},{ }^{1} \mathrm{H}-{ }^{1} \mathrm{H}$ COSY, ${ }^{1} \mathrm{H}-{ }^{1} \mathrm{H}$ ROESY, HSQC and HMBC spectra of 1. ECD spectra of (-)-E315 gnetin $\mathrm{C}$ and (+)-E-gnetin $\mathrm{C}$ compounds. 


\section{References}

Ali, F., Assanta, M.A., Robert, C., 2011. Gnetum africanum: a wild food plant from the African forest with many nutritional and medicinal properties. Journal of Medicinal Food 14, 1289-1297. https://doi.org/10.1089/jmf.2010.0327

Ayton, S., James, S.A., Bush, A.I., 2017. Nanoscale imaging reveals big role for iron in Alzheimer's disease. Cell Chemical Biology 24, 1192-1194. https://doi.org/10.1016/j.chembiol.2017.10.002

Biye, E.H., Balkwill, K., Cron, G.V., 2014. A clarification of Gnetum L. (Gnetaceae) in Africa and the description of two new species. Plant Syst Evol 300, 263-272. https://doi.org/10.1007/s00606-013-0879-6

Boralle, N., Gottlieb, H.E., Gottlieb, O.R., Kubitzki, K., Lopes, L.M.X., Yoshida, M., M. Young, M.C., 1993. Oligostilbenoids from Gnetum venosum. Phytochemistry 34, 1403-1407. https://doi.org/10.1016/0031-9422(91)80038-3

Buffeteau, T., Cavagnat, D., Bisson, J., Marchal, A., Kapche, G.D., Battistini, I., Da Costa, G., Badoc, A., Monti, J.-P., Mérillon, J.-M., Waffo-Téguo, P., 2014. Unambiguous determination of the absolute configuration of dimeric stilbene glucosides from the rhizomes of Gnetum africanum. Journal of Natural Products 77, 1981-1985. https://doi.org/10.1021/np500427v

Buffeteau, T., Lagugné-Labarthet, F., Sourisseau, C., 2005. Vibrational circular dichroism in general anisotropic thin solid films: measurement and theoretical approach. Applied Spectroscopy 59, 732-745. https://doi.org/10.1366/0003702054280568

Chan, S., Kantham, S., Rao, V.M., Palanivelu, M.K., Pham, H.L., Shaw, P.N., McGeary, R.P., Ross, B.P., 2016. Metal chelation, radical scavenging and inhibition of A $\beta 42$ fibrillation by food constituents in relation to Alzheimer's disease. Food Chemistry 199, 185-194. https://doi.org/10.1016/j.foodchem.2015.11.118

Dinis, T.C.., Madeira, V.M.., Almeida, L.., 1994. Action of phenolic derivatives 
(acetaminophen, salicylate, and 5-aminosalicylate) as inhibitors of membrane lipid peroxidation and as peroxyl radical scavengers. Archives of Biochemistry and Biophysics 315, 161-169. https://doi.org/10.1006/abbi.1994.1485

Fernández-Marín, M.I., Guerrero, R.F., García-Parrilla, M.C., Puertas, B., Richard, T., Rodriguez-Werner, M.A., Winterhalter, P., Monti, J.-P., Cantos-Villar, E., 2012. Isorhapontigenin: a novel bioactive stilbene from wine grapes. Food Chemistry 135, 1353-1359. https://doi.org/10.1016/j.foodchem.2012.05.086

Gnetum africanum (PROTA). Plant Resources of Tropical Africa. https://uses.plantnetproject.org/en/Gnetum_africanum_(PROTA) (accessed 26 March 2020)

Hornedo-Ortega, R., Da Costa, G., Cerezo, A.B., Troncoso, A.M., Richard, T., GarciaParrilla, M.C., 2018. In vitro effects of serotonin, melatonin, and other related indole compounds on amyloid- $\beta$ kinetics and neuroprotection. Molecular Nutrition \& Food Research 62, 1700383. https://doi.org/10.1002/mnfr.201700383

Huang, K.-S., Wang, Y.-H., Li, Lin, M., 2000. Five new stilbene dimers from the lianas of Gnetum hainanense. J. Nat. Prod. 63, 86-89. https://doi.org/10.1021/np990382q

Iliya, I., Ali, Z., Tanaka, T., Iinuma, M., Furusawa, M., Nakaya, K., Murata, J., Darnaedi, D., Matsuura, N., Ubukata, M., 2003a. Stilbene derivatives from Gnetum gnemon Linn. Phytochemistry 62, 601-606. https://doi.org/10.1016/S0031-9422(02)00670-2

Iliya, I., Tanaka, I., Iinuma, M., Ali, Z., Furasawa, M., Nakaya, K., 2002. Dimeric stilbenes from stem lianas of Gnetum africanum. HETEROCYCLES 57, 1057-1062. https://doi.org/10.3987/COM-02-9471

Iliya, I., Tanaka, T., Ali, Z., Inuma, M., Furusawa, M., Nakaya, K., Shirataki, Y., Murata, J., Darnaedi, D., Matsuura, N., Ubukata, M., 2003b. Six flavonostilbenes from Gnetum africanum and Gnetum gnemon. Heterocycles 60, 159-166. https://doi.org/10.3987/COM-02-9632

Iliya, I., Tanaka, T., Furasawa, M., Ali, Z., Nakaya, K., Iinuma, M., Shirataki, Y., Murata, J., 
Darnaedi, D., 2001. Four new glucosides of stilbene oligomers from the stem of Gnetum gnemonoides. Heterocycles 55, 2123-2130. https://doi.org/10.3987/COM-019317

Kanmegne, J., Belinga, J.M.O., Degrande, A., Tchoundjeu, Z., 2007. Gender analysis in the commercialization of Gnetum africanum/buchholzianum in the Lékié division in Cameroon. Journal of Food Agriculture and Environment 5, 243-247. https://doi.org/10.1234/4.2007.769

Kantham, S., Chan, S., McColl, G., Miles, J.A., Veliyath, S.K., Deora, G.S., Dighe, S.N., Khabbazi, S., Parat, M.-O., Ross, B.P., 2017. Effect of the biphenyl neolignan honokiol on $\mathrm{A} \beta_{42}$-induced toxicity in Caenorhabditis elegans, $\mathrm{A} \beta_{42}$ fibrillation, cholinesterase activity, DPPH radicals, and iron(II) chelation. ACS Chemical Neuroscience 8, 1901-1912. https://doi.org/10.1021/acschemneuro.7b00071

Kato, E., Tokunaga, Y., Sakan, F., 2009. Stilbenoids isolated from the seeds of Melinjo (Gnetum gnemon L.) and their biological activity. J. Agric. Food Chem. 57, 25442549. https://doi.org/10.1021/jf803077p

Larronde, F., Richard, T., Delaunay, J.-C., Decendit, A., Monti, J.-P., Krisa, S., Mérillon, J.M., 2005. New stilbenoid glucosides isolated from Vitis vinifera cell suspension cultures (cv. Cabernet Sauvignon). Planta Med 71, 888-890. https://doi.org/10.1055/s2005-871294

Li, X.-M., Lin, M., Wang, Y.-H., Liu, X., 2004. Four new stilbenoids from the lianas of Gnetum montanum f. megalocarpum. Planta Medica 70, 160-165. https://doi.org/10.1055/s-2004-815494

Lins, A.P., Ribeiro, M.N.D.S., Gottlieb, O.R., Gottlieb, H.E., 1982. Gnetins: resveratrol oligomers from Gnetum Species. Journal of Natural Products 45, 754-761. https://doi.org/10.1021/np50024a022

Mc.Conathy, J., Owens, M.J., 2003. Stereochemistry in drug action. The Primary Care 
Companion to The Journal of Clinical Psychiatry 05, 70-73. https://doi.org/10.4088/PCC.v05n0202

Mvitu-Muaka, M., Longo-Mbenza, B., Mokondjimobe, E., Gombet, T., Kibokela Ndembe, D., Tulomba Mona, D., Wayiza Masamba, S., 2012. Intake of Gnetum africanum and dacryodes edulis, imbalance of oxidant/antioxidant status and prevalence of diabetic retinopathy in Central Africans. PLOS ONE 7, e49411. https://doi.org/10.1371/journal.pone.0049411

Nguyen, L.A., He, H., Pham-Huy, C., 2006. Chiral drugs: an overview. International Journal of Biomedical Sciences 2, 85-100.

Ogbonnaya, E.C., Chinedum, E.K., 2013. Health promoting compounds and in vitro antioxidant activity of raw and decoctions of Gnetum aficanum Welw. Asian Pacific Journal of Tropical Disease 3, 472-479. https://doi.org/10.1016/S22221808(13)60103-6

Ouabonzi, A., Bouillant, M.L., Chopin, J., 1983. C-glycosyflavones from Gnetum buchholzianum and Gnetum africanum. Phytochemistry 22, 2632-2633. https://doi.org/10.1016/0031-9422(83)80190-3

Papastamoulis, Y., Bisson, J., Temsamani, H., Richard, T., Marchal, A., Mérillon, J.-M., Waffo-Téguo, P., 2015. New E-miyabenol isomer isolated from grapevine cane using centrifugal partition chromatography guided by mass spectrometry. Tetrahedron 71 , 3138-3142. https://doi.org/10.1016/j.tet.2014.08.029

Shimokawa, Y., Hirasawa, Y., Kaneda, T., Hadi, A.H.A., Morita, H., 2012. Cuspidans A and B, two new stilbenoids from the bark of Gnetum cuspidatum. Chemical and Pharmaceutical Bulletin 60, 790-792. https://doi.org/10.1248/cpb.60.790

Sri-in, P., Sichaem, J., Siripong, P., Tip-pyang, S., 2011. Macrostachyols A-D, new oligostilbenoids from the roots of Gnetum macrostachyum. Fitoterapia 82, 460-465. https://doi.org/10.1016/j.fitote.2010.12.008 
Tanaka, T., Iliya, I., Ito, T., Furusawa, M., Nakaya, K., Iinuma, M., Shirataki, Y., Matsuura, N., Ubukata, M., Murata, J., Simozono, F., Hirai, K., 2001. Stilbenoids in lianas of Gnetum parvifolium. Chemical \& Pharmaceutical Bulletin 49, 858-862. https://doi.org/10.1248/cpb.49.858

Waffo Teguo, P., Fauconneau, B., Deffieux, G., Huguet, F., Vercauteren, J., Mérillon, J.-M., 1998. Isolation, identification, and antioxidant activity of three stilbene glucosides newly extracted from Vitis vinifera cell cultures. J. Nat. Prod. 61, 655-657. https://doi.org/10.1021/np9704819

Xu, Q., Lin, M., 1997. Gnetifolin K, a new stilbene diglucoside from Gnetum parvifolium. Chinese Chemical Letters 8, 509-510. 


\section{FIGURES CAPTIONS}

Figure 1. Chemical structures of compound 1 and $\mathbf{2}$ in $\mathrm{CD}_{3} \mathrm{OD}$.

Figure 2. a) Experimental VCD spectra of 1 and 2 in DMSO- $d_{6}$ solution $(50 \mathrm{mM}, 100 \mu \mathrm{m}$ path length). b) Experimental ECD spectra of 1 and $\mathbf{2}$ in EtOH solution $\left(7.710^{-5} \mathrm{M}, 1 \mathrm{~cm}\right.$ path length).

Figure 3. $\mathrm{Fe}(\mathrm{II})$ chelation (\%) activities of pure compounds from Gnetum africanum at different concentrations $(\mu \mathrm{M})$. Statistical analysis was carried out with one-way ANOVA followed by Newman-Keuls multiple comparison post hoc tests. Different letters means significant differences.

*Gallic acid was used as positive control. 
Table 1. ${ }^{1} \mathrm{H}$ and ${ }^{13} \mathrm{C}$ NMR data of compounds 1 and 2 in methanol-d4 at $600 \mathrm{MHz}$ for ${ }^{1} \mathrm{H}$ and $150 \mathrm{MHz}$ for ${ }^{13} \mathrm{C}$

\begin{tabular}{|c|c|c|}
\hline \multirow[b]{2}{*}{ position } & \multicolumn{2}{|c|}{1 or 2} \\
\hline & $\delta_{\mathrm{C}}$, type & $\delta_{\mathrm{H}}(J$ in $\left.\mathrm{Hz})\right)$ \\
\hline $1 \mathrm{a}$ & 136.1, C & \\
\hline $2 \mathrm{a} / 6 \mathrm{a}$ & 126.6, $\mathrm{CH}$ & $7.26 d(8.5)$ \\
\hline $3 a / 5 a$ & $116.5, \mathrm{CH}$ & $7.10 d(8.5)$ \\
\hline $4 a$ & $157.6, \mathrm{C}$ & \\
\hline $7 \mathrm{a}$ & $92.9, \mathrm{CH}$ & $5.4 d(5.1)$ \\
\hline $8 a$ & $55.4, \mathrm{CH}$ & $4.33 d(5.1)$ \\
\hline $9 \mathrm{a}$ & $145.3, \mathrm{C}$ & \\
\hline $10 \mathrm{a} / 14 \mathrm{a}$ & 105.6, CH & $6.13 d(2.2)$ \\
\hline $11 \mathrm{a} / 13 \mathrm{a}$ & $158.3, \mathrm{C}$ & \\
\hline $12 \mathrm{a}$ & $100.8, \mathrm{CH}$ & $6.16 t(2.2)$ \\
\hline $1 b$ & $132.8, \mathrm{C}$ & \\
\hline $2 b$ & $110.3, \mathrm{CH}$ & $7.20 d(2.0)$ \\
\hline $3 b$ & $150, \mathrm{C}$ & \\
\hline $4 b$ & $146.4, \mathrm{C}$ & \\
\hline $5 b$ & $116.8, \mathrm{CH}$ & $7.16 d(8.5)$ \\
\hline $6 b$ & $119.6, \mathrm{CH}$ & $7.08 d d(8.5,2.0)$ \\
\hline $7 b$ & 127.6, CH & $7.05 d(16.3)$ \\
\hline $8 b$ & 127.6, CH & $6.99 d(16.3)$ \\
\hline $9 b$ & $140, \mathrm{C}$ & \\
\hline $10 \mathrm{~b}$ & 107.1, CH & $6.54 b r d$ \\
\hline $11 \mathrm{~b}$ & $154.5, \mathrm{C}$ & \\
\hline $12 b$ & 114.2, C & \\
\hline $13 b$ & $162, \mathrm{C}$ & \\
\hline $14 \mathrm{~b}$ & $98.5, \mathrm{CH}$ & $6.68 \mathrm{brd}$ \\
\hline $3 \mathrm{~b}-O \mathrm{Me}$ & $55.7, \mathrm{CH}$ & $3.92 s$ \\
\hline \multicolumn{3}{|l|}{$4 \mathrm{a}-O-\mathrm{Glc}$} \\
\hline $1^{\prime}$ & 101.2, $\mathrm{CH}$ & $4.92 d(7.6)$ \\
\hline $2^{\prime}$ & $73.6, \mathrm{CH}$ & $3.46 m$ \\
\hline $3^{\prime}$ & $76.8, \mathrm{CH}$ & $3.47 m$ \\
\hline $4^{\prime}$ & $70.1, \mathrm{CH}$ & $3.40 m$ \\
\hline $5^{\prime}$ & $76.8, \mathrm{CH}$ & $3.43 m$ \\
\hline $6^{\prime} \mathrm{a}$ & $61.3, \mathrm{CH}_{2}$ & $3.70 m$ \\
\hline $6^{\prime} \mathrm{b}$ & & $3.89 m$ \\
\hline \multicolumn{3}{|l|}{$4 \mathrm{~b}-O-\mathrm{Glc}$} \\
\hline $1^{\prime \prime}$ & 101.2, CH & $4.92 d(7.4)$ \\
\hline $2^{\prime \prime}$ & $73.6, \mathrm{CH}$ & $3.46 m$ \\
\hline $3^{\prime \prime}$ & $76.8, \mathrm{CH}$ & $3.47 m$ \\
\hline $4^{\prime \prime}$ & $70.1, \mathrm{CH}$ & $3.40 m$ \\
\hline $5^{\prime \prime}$ & $76.8, \mathrm{CH}$ & $3.43 m$ \\
\hline $6 " \mathrm{a}$ & $61.3, \mathrm{CH}_{2}$ & $3.70 m$ \\
\hline $6 " \mathrm{~b}$ & & $3.89 m$ \\
\hline
\end{tabular}

